\title{
ASSESSING THE COMPETITIVENESS OF FIRMS IN THE INDIAN MANUFACTURING SECTOR: AN INTER INDUSTRY ANALYSIS
}

\author{
Pradipta Kumar Sahoo*, Badri Narayan Rath** and Viet Le*** \\ * Corresponding author.Department of Liberal Arts, Indian Institute of Technology Hyderabad, \\ Kandi, Sangareddy, Telangana, India. Email: pradiptaiith@gmail.com \\ ** Department of Liberal Arts, Indian Institute of Technology Hyderabad, Kandi, Sangareddy, \\ Telangana, India. Email: badri@la.iith.ac.in \\ *** School of Business, Law and Entrepreneurship, Swinburne University of Technology, Hawthorn, \\ Australia. Email: clle@swin.edu.au
}

\begin{abstract}
This study measures the competitiveness of Indian manufacturing industries by covering 650 firms from 11 industries using the composite index approach. Firms are classified into two broad groups based on labor-capital intensity and ownership. The study found that capital-intensive industries are more competitive than labor-intensive industries. With regards to ownership of firms, the study finds that foreign-owned firms are more competitive than domestic firms. The study also divides the sample into two sub-periods based on India's Competition Act 2002. The results reveal that competitiveness has slightly increased after the implementation of the Act.
\end{abstract}

Keywords: Competitiveness; ICI index; Labor-intensive; Capital-intensive.

JEL Classifications: D21; D24; D41; L25.

\author{
Article history: \\ Received : June 26, 2021 \\ Revised : July 26, 2021 \\ Accepted : September 04, 2021 \\ Available Online: December 31,2021 \\ https://doi.org/10.21098/bemp.v24i4.1678
}




\section{INTRODUCTION}

The post-1991 reforms through the trade liberalization process brought more trade reforms, de-reservation, and industrial de-licensing policy to the Indian manufacturing sector (Mukhopadhyay and Chakraborty, 2017). These reforms helped in bringing competition strategies to the industries and greater functioning of the market activities in the Indian manufacturing sector. Together with delicensing policy, entry barriers were removed, which enabled domestic firms to become internationally competitive. Competition policies allow firms to grow without depending on others. The injection of competition encourages firms to better utilize existing resources through greater innovation and the production of new products to compete in other markets (Scherer, 1980). Product innovation helps to increase profit, which in turn attracts competitors to enter the market. Competition also encourages firms to reduce costs as well as the managerial and operational slacks and to increase efficiency. Thus, to exist in the market, firms are forced to increase their competitiveness (Kambhampati, 1996; Athreye and Kapur, 2006; Ramaswamy, 2006; Bhavani and Bhanumurty, 2007).

The competitiveness concept has been examined through various approaches, like one-dimensional, two-dimensional, and multidimensional measures (Fischer and Schornberg, 2007; Pushpangadan and Shanta, 2009; Sardana et al., 2016). At the international level, it is measured through the Global Competitiveness Index (GCI) published by the World Economic Forum (WEF, 2019), which includes 12 pillar indicators of competitiveness i.e., "institutions, infrastructure, macroeconomic environment, health and primary education, 'higher education and training', goods market efficiency, labor market efficiency, financial market development, technological readiness, market size, business sophistication, and innovation. ${ }^{1 "}$ Studies by Turner and Golub (1997), and Golub and Hsieh (2000) argue that competitiveness is measured through unit labor cost, whereas studies by O'Farrell and Hitchens (1988) and Cockburn et al. (1999) argue for the domestic and national unit cost of production as a measure of the degree of competitiveness. Baumol et al. (1982) advocates that competition is important for determining the price and output of the industry. Porter (1990), using the Diamond model, defines competitiveness at the organizational level as productivity growth that reflects in the lower cost of the differentiated product and lower prices. He has explained that productivity is the true source of competitive advantage. Studies by Buckley et al. (1988), Lall (2001), Singh et al. (2007), Voulgaris et al. (2013), and Surjaningsih and Permono (2014) measure competition using productivity, profitability, and market share growth.

Several studies have addressed the quantitative and qualitative assessment related to competitiveness. The studies by Martin et al. (1991) and Martin and Stiefelmeyer (2001) show that a firm's market share and profitability are the indicators of relevant sectoral competitiveness. Okada (2005) focuses on competition through industrial price-cost and observes that low-level price-cost industries are more competitive. Similarly, there are a reasonable number of studies that have measured the competitiveness of other countries. Voulgaris and Lemonakis (2014) examine market share growth as a measure of competitiveness

1 https://www3.weforum.org/docs/WEF_TheGlobalCompetitivenessReport2019.pdf 
in the case of Greek manufacturing. According to them, an increase in a firm's market share growth indicates that its competitiveness has increase. Starbird and Agrawal (1996) investigate the competitiveness of US food manufacturing using a survey of 225 food manufacturing firms and discovered a significant relationship between competitiveness and manufacturing strategy. They find that various food manufacturing firms do not achieve competitiveness. Pitelis and Antonakis (2003) analyze that there is interdependence between competitiveness and changes in the share of manufacturing output in the case of Greece manufacturing and find that the differences in manufacturing shares have a positive effect on the competitiveness in Greece manufacturing. Meanwhile, Jin and Moon (2006) investigate the competitive performance of the textile industry in Korea using Porter's Diamond model. They find that the competitive performance of the Korean textile industry has declined as the labor cost and factor conditions are related to each other.

Fischer and Schornberg (2007) empirically examine the competitiveness of the food and drink manufacturing sector of 13 European countries from 1995 to 2002. For the competitiveness calculation, they use the average of a multi-dimensional index constituting growth, productivity, and profitability. They find that the beverage industry has the highest competitiveness score in the European food and drink industries. Ark et al. (2008) undertake the international comparison of the cost competitiveness of manufacturing sectors and find that India and China have a lower level of unit labor cost as compared to Korea, Mexico, Hungary, Poland, which is a good sign of the cost competitiveness of the manufacturing sector. This low unit labor cost is due to the better labor productivity and low average compensation to labor. But China has more disadvantages in terms of unit labor cost than India due to high unit labor cost.

Some recent literature on firm competitiveness in case of India is also measured competitiveness through productivity, profitability, real wage, unit labor cost, firm performances, and firm's export activities (Kathuria, 2013; Mitra et al., 2014, Sharma and Mishra, 2015; Bhattacharya and Narayan, 2015; Mukhopadhyay and Chakraborty, 2017; Sharma, 2018; Opoku et al., 2018; Kim, 2019; Chakradhar and Bairwa, 2020). Kathuria (2013) compares the comparative advantage of India and Bangladesh's clothing manufacturing sectors and explains that India has a comparative advantage over Bangladesh in many clothing products, but it has not been able to increase its share at a faster rate in the world clothing trade. Bhattacharya and Narayan (2015) investigate the long-run relationship between real wage, labor productivity, and the output of India's organized manufacturing sector. They find the long-run elasticities of real wage to be higher than the labor productivity in estimating the output of Indian manufacturing sector.

Our study contributes to the existing literature in the following ways. The existing studies on competitiveness in the Indian manufacturing sector have focused on the single-dimensional measure of firm's or individual industry's competitiveness, but to the best of our knowledge, no study has discussed the multidimensional competitiveness measure for Indian manufacturing firms. Therefore, first, we choose the manufacturing sector as it has a potency to achieve high growth compared to other sectors and in turn can significantly contribute to the nation's growth process. We have attempted to measure the competitiveness of the Indian manufacturing sector with a multidimensional composite measure, 
namely the Industrial Competitiveness Index (ICI), which covers sales growth, labor productivity, and profitability. Although the individual indicators are used for the measurement of competitiveness, we argue that they should not be used separately since they measure different aspects of competitiveness. The importance of these indicators will be further strengthened when they are combined to form a competitiveness index, which is what we do in this study. Second, we divide the sample by equity ownership to investigate the competitiveness of domestic and foreign-owned firms. In the empirical literature, studies found that the magnitude of competitiveness does vary between the type of ownership (Willmore 1986; Goddard et al., 2005). Therefore, it is imperative to know how domestic manufacturing firms compare with foreign-owned firms in terms of competitiveness in India. Finally, we also compare the competitiveness of labor and capital-intensive industries, as existing studies by Hasan et al. (2013) and Veeramani (2012) highlighted that India is a labor-abundant country but its performance in labor-intensive manufacturing has not been satisfactory, and capital-intensive technologies firms are growing faster than labor-intensive technologies firms. The comparison of competitiveness of labor and capital-intensive industries is conducted for the period before and after the implementation of the Competition Act 2002 by measuring the absolute change from one period to another.

Our study offers the following insights. First, the ICI index based on sales growth, labor productivity, and profitability reveals that capital-intensive industries are more competitive than the labor-intensive industries in Indian manufacturing. The study also finds that within labor-intensive industries the 'machinery and equipment' industry is the most competitive, followed by the "automobile" industry as compared with others in the capital-intensive industries. Second, based on ownership, foreign-owned firms are more competitive than domestic firms in Indian manufacturing. Finally, the study also observes the competitiveness of industries after the implementation of the Competition Act, 2002, and finds that the 'machinery and equipment' from the labor-intensive industry and "automobile industry" from the capital-intensive industry rank as the top industries in term of competitiveness in the case of Indian manufacturing sector.

The remaining portion of this article is structured as follows. Section II describes the data and Section III describes the methodology. Section IV reports the empirical estimation of the competitiveness index and discusses the results. The final section V summarizes and concludes the paper.

\section{DATA}

The study measures the competitiveness of Indian manufacturing as a multidimensional index composed of Sales Growth (SG), Labor Productivity (LP), and Profitability (PT) of firms. Sales growth is measured as a percentage change in firm's growth over two consecutive periods, while labor productivity of firms is defined as the ratio of gross sales of firms to employment. Similarly, profitability is defined as the ratio of firm's profit to gross sales. The data on all the variables are collected from ProwessIQ database, which is published by the Centre for Monitoring Indian Economy (CMIE). All the firms are registered on Bombay 
Stock Exchanges (BSE). Our firm size is restricted to 650 firms belonging to 11 manufacturing industries for the period from 1994 to 2017. Since the sales growth variable is estimated, the final data available for the study is from 1995 to 2017 . We also clean the data and eliminate firms that have negative sales. The sales variable of firms is in real terms and has been deflated by using the Wholesale Price Index (WPI) of all-commodities with the base year of 2004-05. As the ProwessIQ database does not provide the employment value of firms, we calculate the labor units as a ratio of wages and salaries of firms to the average wage of the industries where the firm belongs. To obtain the average wage of a particular industry, we divide the Annual Survey of Industry (ASI) data of the total emoluments to total persons engaged in the respective industries (Thomas and Narayanan, 2012; Sharma and Mishra, 2011; Sahoo and Rath, 2018). Following Das et al. (2009), we classified food products, textile, basic metals, non-metallic products, rubber, 'machinery and equipment', and paper products as labor-intensive industries and chemical, pharmaceutical, electrical, and 'automobile and transport equipment' as capitalintensive industries. We considered firms as foreign-owned if foreign equity makes up more than $10 \%$ of their total equity, otherwise they are domestic firms (Franco and Sasidharan, 2010).

\section{METHODOLOGY}

The study's composite index for competitiveness draws based on the United Nations Development Programme's (UNDP's) Human Development Index (HDI), and the food industry's competitiveness index developed by Fischer and Schornberg (2007). Our Composite Index (ICI) uses the arithmetic mean of Sales Growth Index (SGI), Labor Productivity Index (LPI), and Profitability Index (PTI), which we first calculate. As a result, each component variable is given an equal weight to measure competitiveness.

\section{A. ICI Index Measurement}

There are several ways to compute a composite index from a set of variables. The highly conventional method for calculating composite indices is by taking the arithmetic mean of the component variables. An alternative method is principal component analysis and factor analysis based on multiple statistical techniques. The latter method is suitable when the component variables are many and are highly correlated to each other (Gujarati and Porter, 2008; Mitra et al., 2016). In our analysis, the component variables, SG, LP, and PT, exhibit low correlations ${ }^{2}$, and hence we used a single composite index method to calculate the competitiveness of Indian manufacturing firms. This method is globally used for the calculation of the global competitiveness index (WEF, 2019) and global manufacturing competitiveness index (Deloitte, 2016). For the measurement of competitiveness, in the case of Indian manufacturing, the ICI method transforms all the variables into individual indices with scale measurement (UNDP, 2002) and later combines them into three component indices (SGI, LPI, and PTI). Next, the indices are aggregated into the ICI by taking the mean of the indices.

${ }_{2}$ Correlations; SG $\rightarrow$ LP (0.074), SG $\rightarrow$ PT (0.14), $\mathrm{LP} \rightarrow \mathrm{PT}(0.02)$. 
For the construction of the three individual indices, first, we follow the standard process and transform the absolute measure value into a scale value ranging from 0 to 100 . We use the maximum $\left(M_{k}\right)$, minimum $\left(m_{k}\right)$, and actual $\left(A_{k}\right)$ values to calculate the role of individual variable's competitiveness over the year. Thus, the lower value received across firms (i) within an industry $(j)$ over time $(t)$ the less competitive the firms and higher values indicate more competitiveness. The formula for the individual competitiveness index score $\left(I_{k}^{i j t}\right)$ is written as follows:

$$
I_{k}^{i j t}=\left[\left(A_{k}^{i j t}-m_{k}\right) /\left(M_{k}-m_{k}\right)\right]^{*} 100
$$

where the individual dimension for competitiveness are $k=1(\mathrm{SGI}), 2(\mathrm{LPI})$ and 3 (PTI); with $i, j$, and $t$ denoting, respectively, firm, industry, and time $t$. .

In the next step, we combined the individual indices into an ICI by calculating the arithmetic mean of three indices $([S G I+L P I+P T I] / 3)$. As a result, all the indices are given equal weight for the competitiveness measure.

\section{EMPIRICAL RESULTS}

In this section, we present and discuss the empirical results from the estimations.

Table 1 shows the summary statistics of competitiveness indices, i.e., sales growth, labor productivity, and profitability. For the whole manufacturing, the mean values of sales growth, profitability, and labor productivity are 5.04, 2.13, and 2.46 percent, respectively. The standard deviations of sales growth, labor productivity, and profitability are $21.60,3.38$, and 14.10 percent, respectively.

Table 1.

\section{Summary Statistics of ICI Variables}

This table provides the summary statistics of sales growth, labor productivity, and profitability of Indian manufacturing sectors, and various segregated sectors of labor and capital-intensive firms and domestic and foreign-owned firms.

\begin{tabular}{lcccccc}
\hline & Statistics & $\begin{array}{c}\text { All } \\
\text { Manufacturing }\end{array}$ & $\begin{array}{c}\text { Labor- } \\
\text { intensive }\end{array}$ & $\begin{array}{c}\text { Capital- } \\
\text { intensive }\end{array}$ & Domestic & Foreign \\
\hline Sales growth (\%) & Maximum & 687.75 & 687.75 & 478.59 & 687.75 & 276.64 \\
& Minimum & -147.71 & -147.71 & -92.5 & -94.95 & -147.71 \\
& Mean & 5.04 & 4.06 & 5.67 & 4.82 & 6.03 \\
& Std dev & 21.6 & 21.78 & 21.3 & 21.6 & 21.57 \\
\hline Labor & Maximum & 96.94 & 64.45 & 96.94 & 96.95 & 19.94 \\
Productivity & Minimum & 0.033 & 0.033 & 0.12 & 0.038 & 0.033 \\
& Mean & 2.46 & 2.1 & 3.09 & 2.54 & 2.09 \\
& Std dev & 3.38 & 2.72 & 4.13 & 3.62 & 1.84 \\
\hline Profitability(\%) & Maximum & 416.8 & 416.8 & 141.6 & 416.8 & 116.11 \\
& Minimum & -343.31 & -343.31 & -263.72 & -343.31 & -204.4 \\
& Mean & 2.13 & 2.25 & 1.94 & 1.96 & 2.94 \\
& Std dev & 14.1 & 14.78 & 12.96 & 14.19 & 13.65 \\
& Observations & $14950(650)$ & $9131(397)$ & $5819(253)$ & $12282(534)$ & $2668(116)$ \\
\hline
\end{tabular}


Also, we see that the mean values of sales growth and labor productivity of the capital-intensive industries are higher than those of the labor-intensive industries, but the mean value of profitability is higher in case of the labor-intensive industries. For foreign-owned firms, the mean values of sales growth and profitability are higher than those of the domestic firms, but the mean of labor productivity is lower in the foreign-owned firms than the domestic firms. The standard deviation of all variables varies across industries and low standard deviation values are observed in the case of foreign-owned firms compared to the domestic firms. Similarly, the lower standard deviation values of sales growth and profitability are reported in capital-intensive industries compared to labor-intensive industries.

\section{A. ICI of Labor and Capital-intensive Industries}

The annual ICI index of all labor and capital-intensive industries are averaged and plotted in Figures 1 and 2. When comparing labor-intensive industries with capital-intensive industries, Figure 1 indicates that labor-intensive industries are more competitive than capital-intensive industries from 1995 to 2003 . However, from 2004 onwards, capital-intensive firms are more competitive than laborintensive firms. As a result, although capital-intensive industries are more competitive than labor-intensive industries in the recent period, the difference is very negligible. Since this is a composite index, which depends on sales growth, labor productivity, and profitability indices, we examine the role of these constituent indices. For labor and capital-intensive industries, labor productivity has significantly increased, as clearly shown in Figure 2. Although profitability and productivity trends are fluctuating, they contribute to increasing the ICI of Indian manufacturing industries.

Figure 1.

\section{ICI of Labor and Capital-intensive Industries}

The figure shows the industrial competitiveness index of labor and capital-intensive industries. LICI and KICI denote the labor and capital-intensive industrial competitiveness indices, respectively. The sample period is from 1995 to 2017 for 397 labor-intensive and 253 capital-intensive firms. The source of the data is from CMIE ProwessIQ.

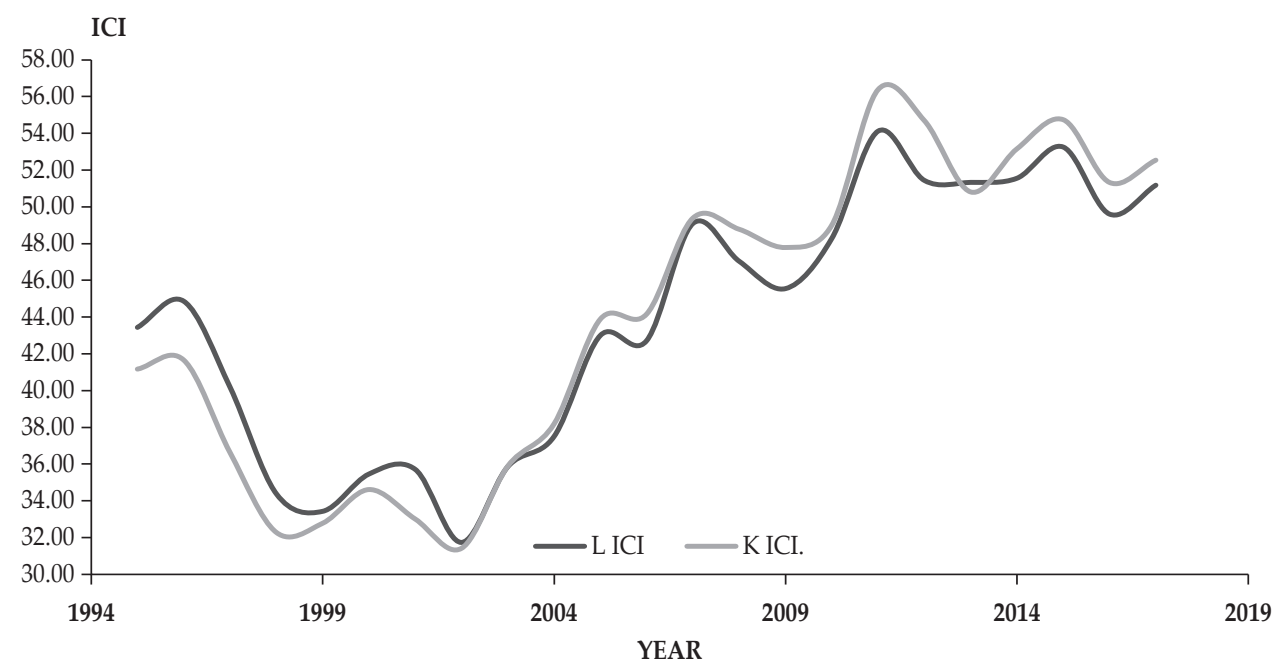


Figure 2.

\section{Individual Components of Labor and Capital-intensive Industries}

The figure shows Sales Growth (SG), Labor Productivity (LP) and Profitability (PP) as individual components of the ICI index of labor and capital-intensive industries. The sample period is from 1995 to 2017 for 397 labor-intensive and 253 capital-intensive firms. The source of the data is from CMIE ProwessIQ.

Labor-intensive

\section{COMPONENT INDEX}
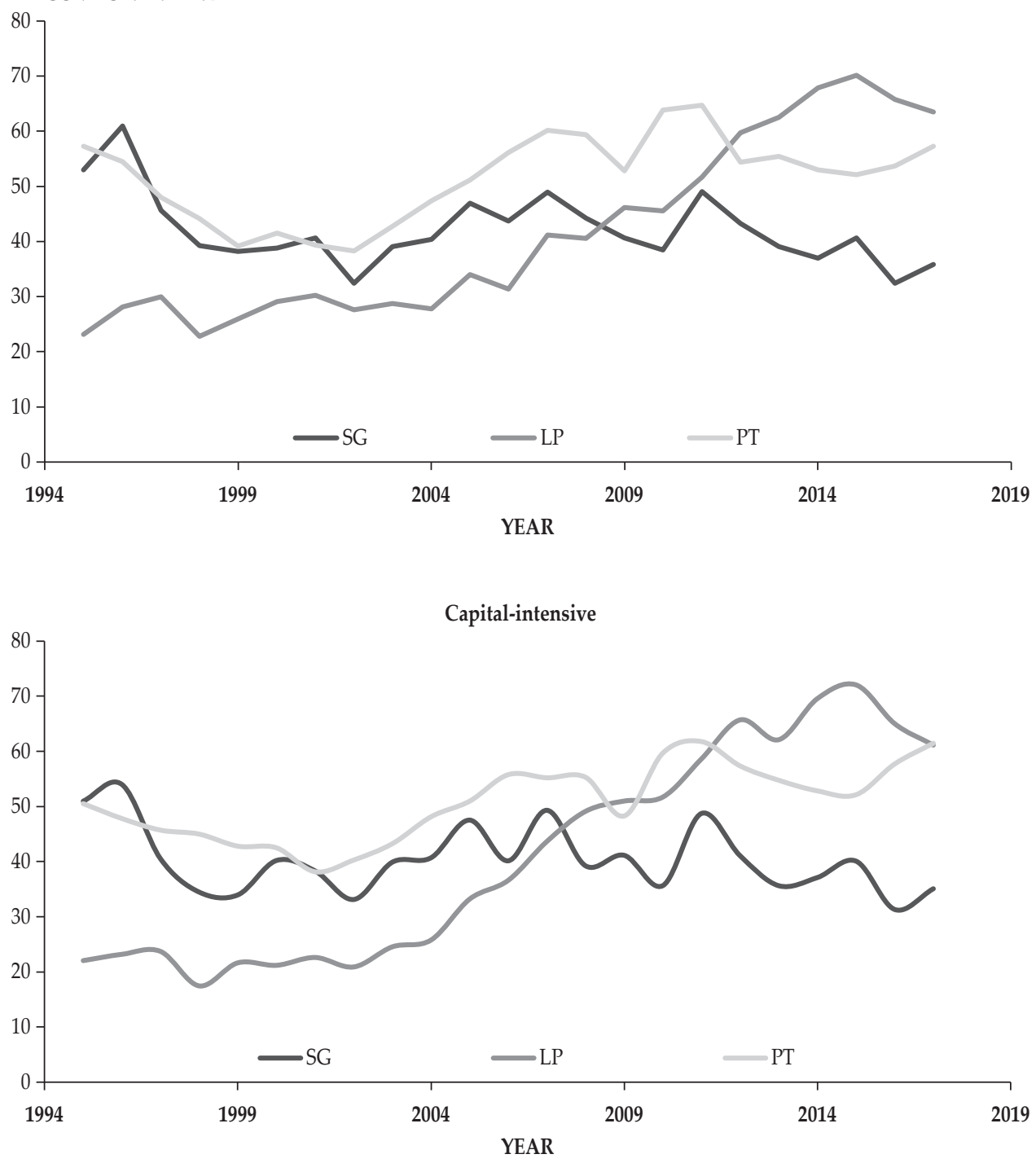
B. ICI of Domestic and Foreign-owned Firms

Figure 3.

\section{Foreign-owned and Domestic ICI Indices}

The figure shows the industrial competitiveness indices of the foreign-owned and domestic firms. The sample period is from 1995 to 2017 for 534 domestic and 116 foreign-owned firms. The source of the data is from CMIE ProwessIQ.

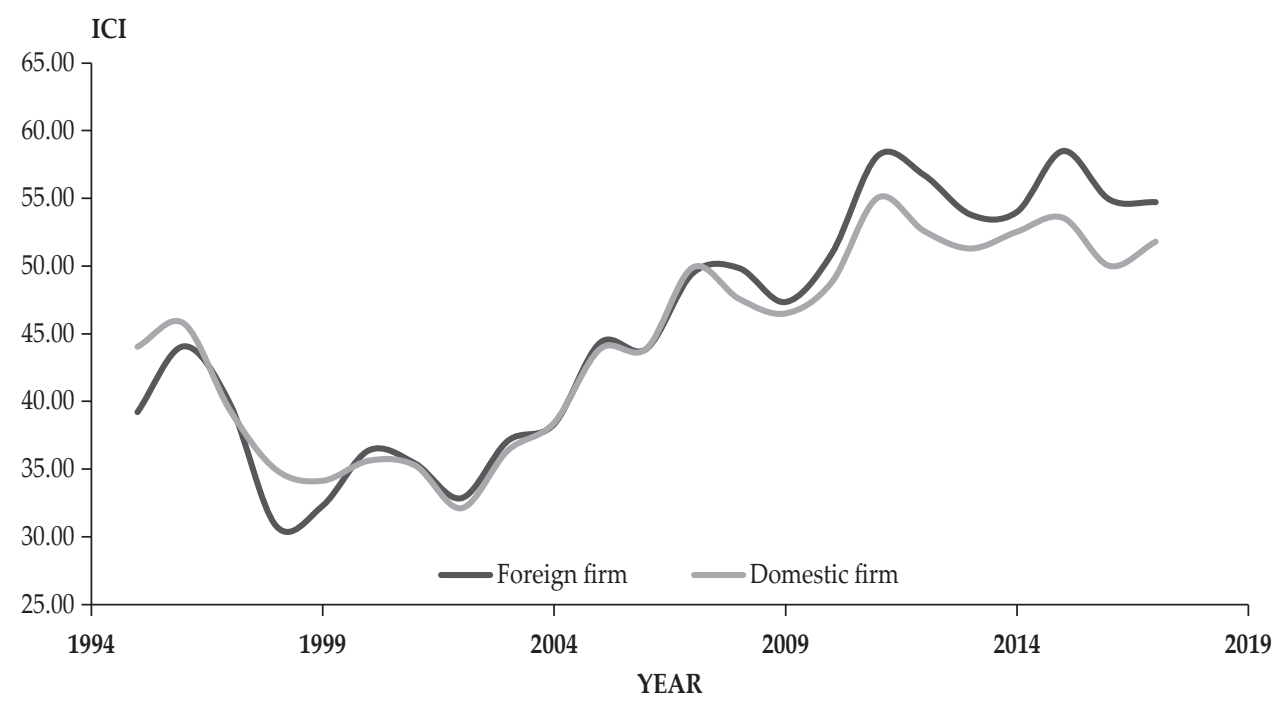

Figure 3 shows the dynamics of competitiveness of foreign-owned and domestic firms measured in terms of our composite competitiveness index. We see that, initially from 1995 to 1999, domestic firms were more competitive. From 2000 to 2007, the competition in both sectors were rising and were similar. After 2007 foreign-owned firms surpassed domestic firms in terms of competitiveness, indicating that, in the recent period, foreign-owned firms became more competitive. However, the competition level of both sectors is very close. 
Figure 4 .

Individual Components of Domestic and Foreign-owned Firms

The figure shows Sales Growth (SG), Labor Productivity (LP) and Profitability (PP) as individual components of ICI index of domestic and foreign-owned firms. The sample period is from 1995 to 2017 for 116 foreign firms and 534 domestic firms. The source of the data is from CMIE ProwessIQ.

Domestic

\section{COMPONENT INDEX}
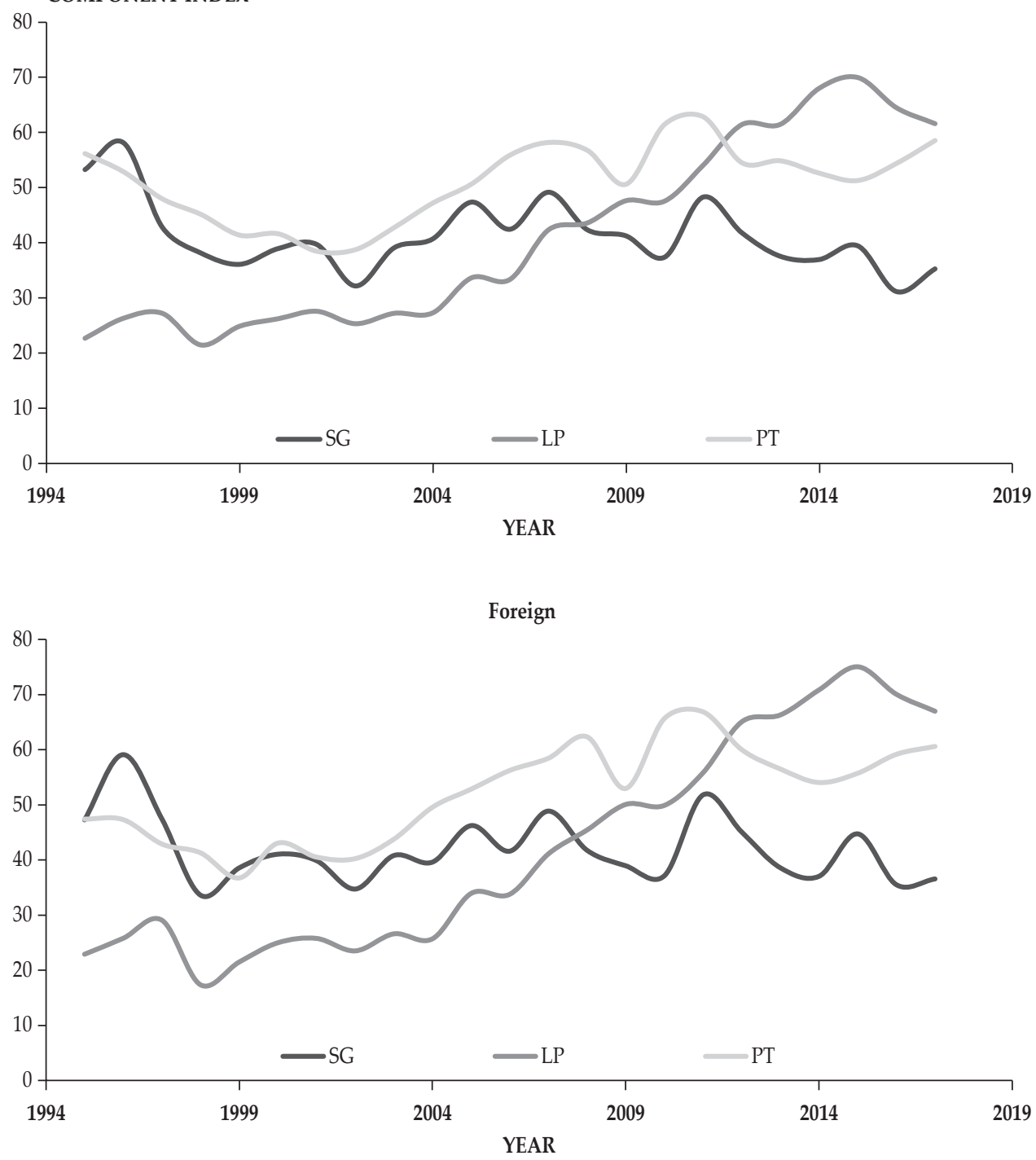

Figure 4 shows that our composite competitiveness (ICI) is the weighted combination of three indices of domestic and foreign-owned firms. Here, we see that labor productivity experienced an increasing trend up to 2015, but after that, it declined. In contrast, sales growth and profitability trends fluctuated over the years with the former clearly declining. Thus, we observed that the increase in 
the composite competitiveness index for domestic firms was largely due to labor productivity. This also supports the theory of unit labor cost of competitiveness, whereby labor productivity experienced a decline in the unit labor cost as industries become more competitive (Ark et al., 2008). Similarly, for foreign-owned firms, we see that the labor productivity index played a major role relative to the other indices in the composite index. Here, the labor productivity index increased throughout the sample period, whereas the other indices fluctuated during the same period.

After measuring trends of competitiveness, we measure the absolute change in competitiveness for the individual industries and report these results in Table 2. To ensure robustness, we divide the whole sample into two periods, before and after the implementation of the Competition Act of 2002, to see whether there are any significant changes after the introduction of this act. The Competition Act 2002, implemented by the Competition Commission of India, came into existence in 2002 as a transformation of the Monopolies and Restrictive Trade Practices Act. This Act allowed the economy to become more as restrictive trade policies were removed. This policy aimed to improve the Monopolies and Restrictive Trade Practices Act by promoting product quality, innovation, and at the same time restricting the concentration of economic power and unfair trade practices ${ }^{3}$. We calculated the average values of competitiveness from 1995 to 2002 and from 2003 to 2017 and ranked them to see the changes in competitiveness.

From Table 2, we see that, for labor-intensive industries, the competitiveness ranking is headed by the 'machinery and equipment' with the highest change of ICI (21.05) from 1995-2002 to 2003- 2017. Besides, paper products and non-metallic products are the only industries that gained significantly on their positions in overall competitiveness by securing second and third ranks. The textiles and basic metals industries had the highest competitiveness rank before the implementation of the Competition Act, but their ranks declined by six and three levels, respectively and secured the lowest competitiveness scores among the industries. this is due to the lowest absolute change in sales growth, i.e., -8.35 and -4.87 , respectively. In addition, the ranks of rubber and food products reduced by up to one and three levels, respectively. For capital-intensive industries, the automobile and transport industry maintained their competitive ranks in top positions both before and after the implementation of the Competition Act. Notably, chemical industry has improved its rank and became the second-highest competitive industry among the capital-intensive industries. This development is due to improvements in labor productivity and profitability. But ranks of pharma and electrical industries reduced by one level and they became the least competitive industries. The reduction of their ranks is induced by low sales growth, as the absolute change of sales growth in these industries are 0.08 and -1.66 , respectively. 


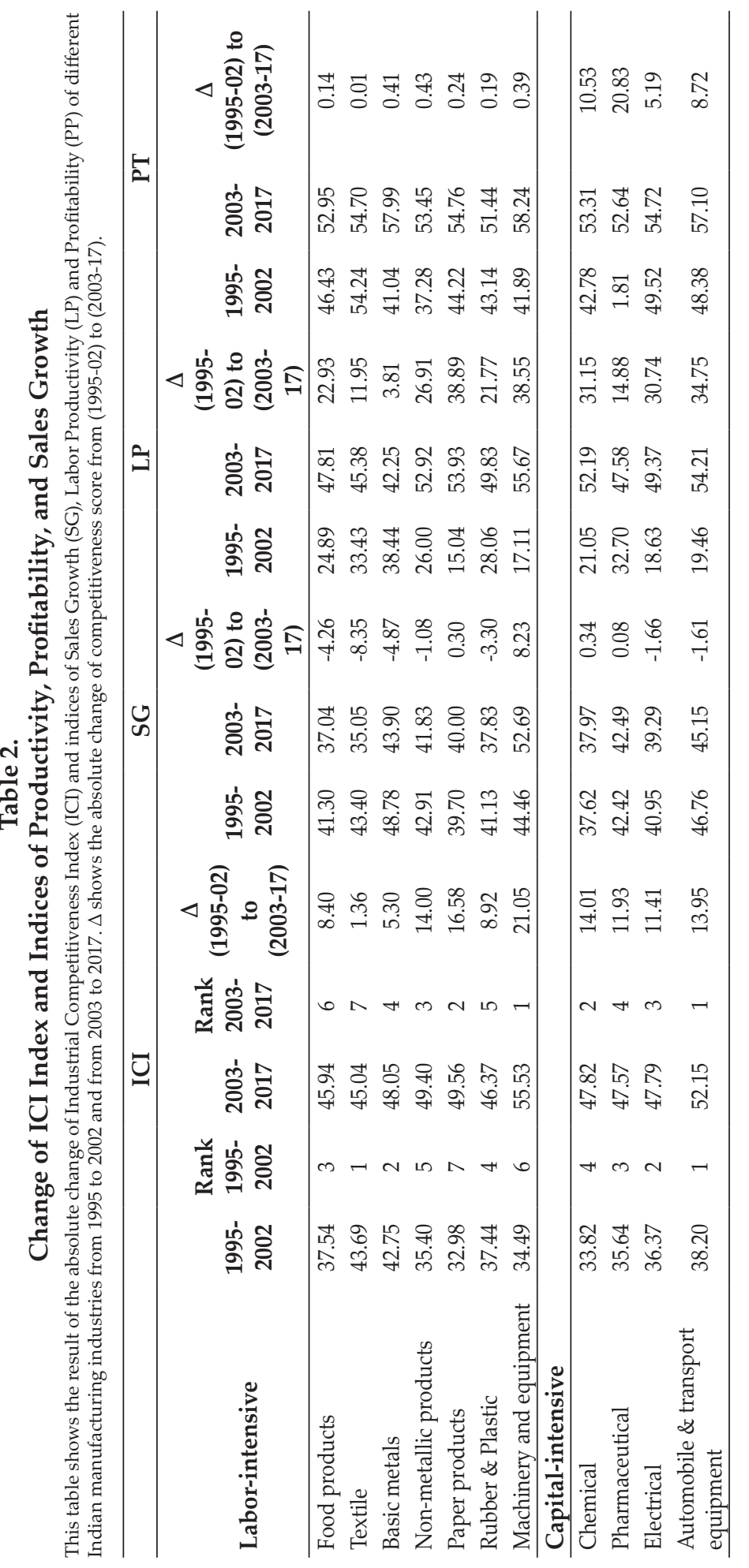


Looking at the changes in the three individual indices (i.e., SG, LP, and PT), it is clear that two indices, i.e., productivity and profitability, increased, whereas sales growth index declined during the sub-periods in all the cases in the labor and capital-intensive industries, except for 'machinery and equipment', paper, chemical and pharmaceutical industries. Hence, we can say that labor productivity and profitability have played a vital role in increasing the ICI index value over the sample period.

\section{Discussion of the Result}

We summarized our findings in Figures 1-4 and Tables 1-2 to illustrate the nature of the competitiveness of the Indian manufacturing industries. Our findings reveal that, in recent times, capital-intensive industries are more competitive than laborintensive industries, and that labor productivity plays a dynamic role in both types of industries. Our result supports the idea by Ark et al. (2008) and Bhattacharya and Narayan (2015) that labor productivity performs a major role in the competitiveness of Indian manufacturing industries. Bhattacharya and Narayan (2015) find that the long-run elasticities of labor productivity plays a vital role in the output of the Indian manufacturing sectors. Our results are well connected to the HeckscherOhlin (1919) theorem in that, India, being a labor-abundant economy, is making use of her labor inputs as reflected in our competition indices during the period 1995 to 2003. After 2004, the results suggest that the country shifted towards capital intensity. This might be due to the fact that, in recent times, the capitalintensive industries have become more dependent on advanced technologies and benefit greatly from this as compared to others. We also observed that, from 2008 onwards, foreign-owned firms became more competitive than domestic firms. This is also consistent with past research (Aitken and Harrison, 1999; Voicu, 2004; Bellak, 2004; Kosová, 2010). This result helps us to understand the underlying mechanism driving foreign-owned firms to become more competitive. As Bellak (2004) noted, the performance gap between foreign-owned and domestic firms arises due to productivity, technology, profitability, wage, and growth. In other words, foreign-owned firms are better resource-endowed in terms of technology, capital, brand, and management practices. Such strengths are reflected in the products and services of these firms, which make them better than the domestic firms. Voicu (2004) argues that Romania's foreign-owned firms are performing well because they are technologically superior to the domestic firms. We can also argue that the proper utilization of resources and excellent export activities help foreign-owned firms to be more competitive relative to domestic firms.

By measuring the ICI after the implementation of the Competition Act in 2002, we find that the 'machinery and equipment' industry has improved its rank to the top from level six for the labor-intensive industries, while the 'automobile and transport equipment' industry is maintained its rank at the top position for the capital-intensive industries. The textile industry has experienced a sales downturn, resulting in it declining to the first lowest position after the implementation of the Act. The strong competitiveness of the 'automobile and transport equipment' is supported by the Society of Indian Automobile Manufacturers report (SIAM, 2018), which shows that high sales growth in the automobile industries. The decline 
in sales of the textile industry is also supported by Kathuria (2013), who finds that India has a comparative advantage over its competitors in several clothing products, but it has not been able to increase its share at a faster rate in the global clothing trade.

\section{CONCLUSION}

The study develops a multidimensional composite index, the Industrial Competitiveness Index (ICI), comprising sales growth, productivity, and profitability, to measure the competitiveness of the Indian manufacturing industry. The composite index allows for the comparison of the relative competitiveness of the labor and capital-intensive industries over time. In addition, firm's equity ownership is used to better analyze the domestic and foreign-owned firms' competitiveness. The results indicate that the capital-intensive industries are more competitive than the labor-intensive industries. Within the labor-intensive industries, the 'machinery and equipment' industry is the most competitive, whereas within the capital-intensive industries, the automobile industry is more competitive than others. After the implementation of the Competition Act 2002, the 'machinery and equipment' industry from the labor-intensive cluster and the automobile industry from the capital-intensive cluster are the most competitive industries in the Indian manufacturing sector. Besides, among the domestic and foreign-owned firms, we find that, in recent times (i.e., after 2008), foreign-owned firms are relatively more competitive than domestic firms.

Thus, our study suggests that the labor-intensive industry can become more competitive by focusing on profitability and sales growth and at the same time by adopting new techniques of production to its production process to increase labor productivity. Also, the government should boost competition in less competitive industries by improving their sales growth, labor productivity, and profitability through supportive schemes like "make in India" programme and other initiatives. Domestic firms are less competitive and hence the government should focus on improving the competitiveness of these firms to boost the performance of the Indian economy.

Acknowledgments: The authors gratefully acknowledge the valuable suggestions received from the Managing Editor Professor Paresh Kumar Narayan, and anonymous referees on the earlier version, which substantially improved this paper. All errors are our own.

\section{REFERENCES}

Aitken, B., \& Harrison, A. (1999). Do Domestic Firms Benefit from Foreign Investment? Evidence from Venezuela. American Economic Review, 89, 605-618.

Ark, B.V., Azeez, E.A., Chen, V., \& Kumar, U. (2008). The Cost Competitiveness of Manufacturing in China and India: An Industry and Regional Perspective. Indian Council for Research on International Economic Relations, New Delhi, Working Paper No. 228. 
Athreye, S., \& Kapur, S. (2006). Industrial Concentration in a Liberalising Economy: A Study of Indian Manufacturing. The Journal of Development Studies, 42, 981999.

Baumol, W. J., Panzar, J. C., \& Willig, R. D. (1982). Contestable Markets and the Theory of Industry Structure. New York: Harcourt Brace Jovanovich Inc.

Bellak, C., (2004). How Domestic and Foreign Firms Differ and Why Does it Matter? Journal of Economic Surveys, 184, 483-514.

Bhattacharya, M., \& Narayan, P. (2015). Output and Labor Productivity in Organized Manufacturing: A Panel Cointegration Analysis for India. International Journal of Production Economics, 170, 171-177.

Bhavani, T. A., \& Bhanumurthy, N. R. (2007). The State of Competition in the Indian Manufacturing Sector. Research report Institute of Economic Growth, New Delhi.

Buckley, P. J., Pass, C. L., \& Prescott, K. (1988). Measures of International Competitiveness: A Critical Survey. Journal of Marketing Management, 4, 175200.

Chakradhar, J., \& Bairwa, A. K. (2020). Employment Probabilities and Workforce Distribution in the Indian Manufacturing Sector: A State-level Analysis. Bulletin of Monetary Economics and Banking, 23, 55-82.

Cockburn, J., Siggel, E., Coulibaly, M., \& Vézina, S. (1999). Measuring Competitiveness and its Sources: The Case of Mali's Manufacturing Sector. Canadian Journal of Development Studies, 20, 491-519.

Das, D. K., Wadhwa, D., \& Kalita, G. (2009). The Employment Potential of Labor Intensive Industries in India's Organized Manufacturing. Indian Council for Research on International Economic Relations. Working Paper, No. 236.

Deloitte. (2016). Global Manufacturing Competitiveness Index. Deloitte. Retrived: https://www2.deloitte.com/global/en/pages/manufacturing/articles/globalmanufacturing-competitiveness-index.html.

Fischer, C., \& Schornberg, S. (2007). Assessing the Competitiveness Situation of EU Food and Drink Manufacturing Industries: An Index-based Approach. Agribusiness, 23, 473-495.

Franco, C., \& Sasidharan, S. (2010). MNEs, Technological Efforts and Channels of Export Spillover: An Analysis of Indian Manufacturing Industries. Economic Systems, 34, 270-288.

Goddard, J., Tavakoli, M., \& Wilson, J. (2005). Determinants of Profitability in European Manufacturing and Services: Evidence from A Dynamic Panel Model. Applied Financial Economics, 15, 1269-1282.

Golub, S. S., \& Hsieh, C. T. (2000). Classical Ricardian Theory of Comparative Advantage Revisited. Review of International Economics, 8, 221-234.

Gujarati, D., \& Porter, C., (2008). Basic Econometrics (5th ed.). New York, NY: McGraw-Hill Education.

Hasan, R., Mitra, D., \& Sundaram, A. (2013). What Explains the High Capital Intensity of Indian Manufacturing? Indian Growth and Development Review, 6, 212-241.

Heckscher, E. (1919). The Effects of Foreign Trade on the Distribution of Income. Ekonomisk Tidskrift, 21, 497-512. 
Jin, B., \& Moon, H. (2006). The Diamond Approach to the Competitiveness of Korea's Apparel Industry: Michel Porter and Beyond. Journal of Fashion Marketing and Management, 10, 195-208.

Kambhampati, U. S. (1996). Industrial Concentration and Performance: A Study of the Structure, Conduct and Performance of Indian Industry. New Delhi: Oxford University Press.

Kathuria, L. (2013). Analyzing Competitiveness of Clothing Export Sector of India and Bangladesh: Dynamic Revealed Comparative Advantage Approach. Competitiveness Review: An International Business Journal, 23, 131-57.

Kim, M. (2019). Export Competitiveness of India's Textiles and Clothing Sector in the United States. MDPI Economies, 7, 4-7. Doi:10.3390/economies7020047.

Kosová, R. (2010). Do Foreign Firms Crowd out Domestic Firms? Evidence from the Czech Republic. The Review of Economics and Statistics, 92, 861-881.

Lall, S. (2001). Competitiveness, Technology and Skills. Cheltenham, UK, Northampton, MA, USA: Edward Elgar.

Martin, L., \& Stiefelmeyer, K. (2001). A Comparative Analysis of Productivity and Competitiveness in Agri-food Processing in Canada and the United States. George Morris Centre. Retrived: https://core.ac.uk/download/pdf/6407402.pdf.

Martin, L., Westgren, R., \& Van Duren, E. (1991). Agribusiness Competitiveness Across National Boundaries. American Journal of Agricultural Economics, 73, 1456-1464.

Mitra, A., Sharma, C., \& Varoudakis, M. A. V. (2014). Trade Liberalization, Technology Transfer, And Firms' Productive Performance: The Case of Indian Manufacturing. Journal of Asian Economics, 33, 1-15.

Mukhopadhyay, J., \& Chakraborty, I. (2017). Competition and Industry Performance: A Panel VAR Analysis in Indian Manufacturing Sector. Journal of Quantitative Economics. 15, 343-366.

O'Farrell, P. N., \& Hitchens, D. M. (1988). The Relative Competitiveness and Performance of Small Manufacturing Firms in Scotland and the Midwest Ireland: An Analysis of Matched Pairs. Regional Studies, 22, 399-416.

Okada, Y. (2005). Competition and Productivity in Japanese Manufacturing Industries. NBER, Working Paper, No. 11540.

Opoku, E. E., Yan, I. K. M., \& Hynes, K. (2018). Reaching up and Reaching out: The Impact of Competition On Firms' Productivity and Export Decisions. Pacific Economic Review, 25, 69-101.

Pitelis, C., \& Antonakis, N. (2003). Manufacturing and Competitiveness: The case of Greece. Journal of Economic Studies, 30, 535-547.

Porter, M. E. (1990). Competitive Advantage of Nation. New Yerk. The Free Press.

Pushpangadan, K. \& Shanta, N. (2009). The Dynamics of Competition Understanding India's Manufacturing Sector. Oxford University Press: New Delhi.

Ramaswamy, K. V. (2006). State of Competition in the Indian Manufacturing Industry. ch.12 (pp.155- 64) in Mehta, Pradeep S. (ed.). Towards a Functional Competition Policy for India. Consumer Unity \& Trust Society (CUTS), Jaipur, India.

Sahoo, P. K., \& Rath, B. N. (2018) Productivity Growth, Efficiency Change and Source of Inefficiency: Evidence from the Indian Automobile Industry. International Journal of Automotive Technology and Management, 18, 59-74. 
Sardana, D., Terziovski, M., \& Gupta N. (2016). The Impact of Strategic Alignment and Responsiveness to Market on Manufacturing Firm's Performance. International Journal of Production Economics, 177, 131-138.

Scherer, F. M. (1980). Industrial Market Structure and Economic Performance. Chicago: Rand McNally.

Sharma, C. (2018). Exporting, Access of Foreign Technology, and Firms' Performance: Searching the Link in Indian Manufacturing. The Quarterly Review of Economics and Finance, 68, 46-62.

Sharma, C., \& Mishra, R. K. (2011). Does Export and Productivity Growth Linkage Exist? Evidence from the Indian Manufacturing Industry. International Review of Applied Economics, 25, 633-652.

Sharma, C., \& Mishra, R. K. (2015). International Trade and Performance of Firms: Unraveling Export, Import and Productivity Puzzle. The Quarterly Review of Economics and Finance, 57, 64-71.

SIAM, (2018). Society of Indian Automobile Manufacturers Report 2018. Retrieved from http://www.siamindia.com/publications.aspx?mpgid=42\&pgidtrail=45.

Singh, R. K., Garg S. K., \& Deshmukh, S. G. (2007). Strategy Development for Competitiveness: A Study on Indian Auto Component Sector. International Journal of Productivity and Performance Management, 56, 285-304.

Starbird, S. A., \& Agrawal, N. (1996). Competitive Food Manufacturing: Evidence from the 1994 Competitive Manufacturing Survey. Agribusiness, 12, 525-539.

Surjaningsih, N., \& Permono, B. P. (2014). The Dynamics of Total Factor Productivity of Medium and Large Manufacturing in Indonesia. Bulletin of Monetary Economics and Banking, 16, 259-288.

Thomas, R., \& Narayanan, K. (2012). Productivity Heterogeneity and Firm-Level Exports: Case of the Indian Manufacturing Industry. In The 11th Annual GEP Postgraduate Conference. University of Nottingham, UK.

Turner, A., \& Golub, S. S. (1997). Towards a System of Unit Labor Cost-based Competitiveness Indicators for Advanced, Developing and Transition Countries. Staff Studies for the World Economic Outlook, IMF.

Veeramani, C. (2012). Anatomy of India's Merchandise Export Growth, 1993-94 to 2010-11. Economic and Political Weekly, XLVII , 94-104.

Voicu, I. (2004). Are Foreign Subsidiaries Technologically Superior to Local Firms? Eastern European Economics, 42, 5-32.

Voulgaris, F., \& Lemonakis, C. (2014). Competitiveness and Profitability: The Case of Chemicals, Pharmaceuticals and Plastics. The Journal of Economic Analysis, 11, 46-57.

Voulgaris, F., Papadogonas, T., \& Lemonakis. C. (2013). Drivers of Competitiveness in the Manufacturing Industry: The Case of Technology Sectors in Greece. Journal of Economics and Development Studies, 1, 32-40.

WEF. (2019). The Global Competitiveness Report (2019). Retrieved from: http://www3. weforum.org/docs/WEF_TheGlobalCompetitivenessReport2019.pdf.

Willmore, L. (1986). The Comparative Performance of Foreign and Domestic Firms in Brazil. World Development, 14, 489-502. 
This page is intentionally left blank 